\title{
Deoxyribonucleic Acid Relatedness Among Major Human Enterococci
}

\author{
R. G. KNIGHT,* D. M. SHLAES, AND L. MESSINEO \\ Medical, Laboratory, and Research Services, Cleveland Veterans Administration Medical Center and Cleveland State \\ University, Cleveland, Ohio 44106
}

\begin{abstract}
Strains of enterococci obtained from the American Type Culture Collection and the Centers for Disease Control were examined for deoxyribonucleic acid homology by using the $\mathrm{S} 1$ nuclease technique. The strains studied segregated into four homology groups. All five Streptococcus faecium strains were included in a single homology group (group III), and both Streptococcus faecalis strains were included in a separate homology group (group IV). Of eight "Streptococcus durans" strains, six fell into one homology group (group I), and two fell into a second homology group (group II). The four homology groups were easily distinguished phenotypically. All eight " $S$. durans" strains were inactive on mannitol, sorbitol, and arabinose. Group I strains clotted litmus milk but did not form acid from sucrose. Group II strains did not clot litmus milk but formed acid from sucrose. These results are consistent with a classification scheme in which " $S$. durans" is a separate species. We propose that the strains included in homology group I be designated Streptococcus durans sp. nov. and that strain ATCC 19432 be the type strain of this species. The two strains in homology group II may represent a new species, but the data supporting such a proposal are presently insufficient.
\end{abstract}

Although the enterococci have been extensively studied, the taxonomic status of strains within this group, particularly strains of Streptococcus faecium and "Streptococcus durans," remains controversial $(2-6,8,9,12,14-16)$. " $S$. durans" was first proposed in 1937 by Sherman and Wing (14). Deibel et al. were the first authors to recommend that the " $S$. durans" strains should be classified as a variety of $S$. faecium (2), a suggestion supported by other workers $(6,8)$. However, Facklam believes that " $S$. durans" deserves species status on the basis of physiological and biochemical characteristics that appear to clearly separate these strains from other enterococcal species $(3,4)$. On the other hand, the Approved Lists of Bacterial Names states that " $S$. faecium" (synonym, ' $S$. durans') is the correct name for designating these organisms (15).

In a recent, large numerical taxonomic study of streptococci, Bridge and Sneath examined seven $S$. faecium strains, which were divided into four phena; only two " $S$. durans" strains, which fell into a single phenon along with three $S$. faecium strains, were studied (1). A study of deoxyribonucleic acid (DNA) homology among enterococcal strains included only one " $S$. durans" strain which was not homologous with the $S$. faecium or Streptococcus faecalis strains used. This study did not include type strains, and there was a suggestion that some of the strains utilized were poorly identified phenotypically (9). Another recent study of DNA homology among enterococci included 7 " $S$. durans" strains, including the former type strain, and $11 \mathrm{~S}$. faecium strains, including the type strain (5). Four " $S$. durans" isolates were homologous with $S$. faecium, whereas three isolates were not, but the latter were homologous with each other. There remains some question as to the identification of some of the strains used in this study, although the data appear to support species status for some strains classified as "S. durans."

The primary purpose of the present study was to examine the DNA relatedness of well-established strains of entero-

\footnotetext{
* Corresponding author.
}

cocci obtained from the American Type Culture Collection and the Centers for Disease Control, with special concentration on the relationship between $S$. faecium and " $S$. durans." From our results, we describe Streptococcus durans sp. nov. and demonstrate a second homology group within "S. durans," which may, after additional study, prove to be a new species.

\section{MATERIALS AND METHODS}

Bacterial strains. The bacterial strains used in this study are listed in Table 1. Both phenotypic tests and DNA hybridization were performed with all of the strains listed.

Phenotypic tests. The phenotypic traits used to characterize the organisms used in this study are shown in Table 2. The tests for hemolysis, bile-esculin, $6.5 \% \mathrm{NaCl}$ tolerance (salt tolerance), inulin, and clot formation in litmus milk were all performed by using the conventional methods described by Facklam (3). The Minitek (BBL Microbiology Systems, Cockeysville, Md.) disk method was used to detect acid production from lactose, D-mannitol, sorbitol, arabinose, raffinose, and sucrose, as described by Setterstrom et al. (13). The presence of group D antigen was determined by the Streptex test (latex test) for streptococcal grouping (Wellcome Reagents Ltd., Beckenham, England) and the Phadebact Strep D test (coagglutination test) for identification of group D streptococci (Pharmacia Diagnostics, Piscataway, N.J.). The standardized Kirby-Bauer method and criteria for interpretation were used for clindamycin and tobramycin susceptibility testing, as described by the $\mathrm{Na}$ tional Committee for Clinical Laboratory Standards.

Growth and lysis of cells. Each organism was grown in 1.5 liters of Trypticase soy broth (BBL) for 18 to $24 \mathrm{~h}$ at 35 to $37^{\circ} \mathrm{C}$ in ambient air to late logarithmic or stationary phase. The cells were harvested by centrifugation at $13,000 \times g$ and $5^{\circ} \mathrm{C}$ by using a Sorvall model RC5B refrigerated centrifuge. The pellet was suspended in $100 \mathrm{ml}$ of a 1:5 dilution of salineethylenediaminetetraacetate buffer $(0.15 \mathrm{M} \mathrm{NaCl}, 0.01 \mathrm{M}$ sodium ethylenediaminetetraacetate, $\mathrm{pH} 8.0$ ). Lysozyme was added to a final concentration of $0.1 \mathrm{mg} / \mathrm{ml}$, and the 
TABLE 1. Enterococcal strains used in this study

\begin{tabular}{|c|c|c|c|}
\hline $\begin{array}{l}\text { Homo- } \\
\text { logy } \\
\text { group }\end{array}$ & Species & Strain & Source and comments ${ }^{a}$ \\
\hline \multirow[t]{4}{*}{ I } & "S. durans" & $\begin{array}{l}\text { ATCC } 19432^{\mathrm{T} b} \\
\text { CDC SS } 497\end{array}$ & $\begin{array}{l}\text { ATCC, former type strain } \\
\text { CDC strain from Analytab } \\
\text { Products; source un- } \\
\text { known }\end{array}$ \\
\hline & & CDC S\$661 & $\begin{array}{l}\text { CDC strain from Analytab } \\
\text { Products; source un- } \\
\text { known }\end{array}$ \\
\hline & & CDC SS8 & $\begin{array}{l}\text { CDC strain from Analytab } \\
\text { Products; source un- } \\
\text { known }\end{array}$ \\
\hline & & $\begin{array}{l}\text { ATCC } 6056 \\
\text { ATCC } 11576\end{array}$ & $\begin{array}{l}\text { ATCC; human feces } \\
\text { ATCC; cheddar cheese }\end{array}$ \\
\hline \multirow[t]{2}{*}{ II } & "S. durans" & CDC $976-79$ & $\begin{array}{l}\text { CDC (R. Facklam); refer- } \\
\text { ence strain; cattle feces }\end{array}$ \\
\hline & & CDC $1709-79$ & $\begin{array}{l}\text { CDC (R. Facklam); spu- } \\
\text { tum }\end{array}$ \\
\hline \multirow[t]{4}{*}{ III } & S. faecium & ATCC $19434^{\mathrm{T}}$ & $\begin{array}{l}\text { ATCC; type strain; } \\
\text { source not indicated }\end{array}$ \\
\hline & & CDC 3781-73 & $\begin{array}{l}\text { CDC (R. Facklam); } \\
\text { source unknown }\end{array}$ \\
\hline & & $\begin{array}{l}\text { CDC } 1318-77 \\
\text { CDC } 3-74\end{array}$ & $\begin{array}{l}\text { CDC (R. Facklam); urine } \\
\text { CDC (R. Facklam); blood }\end{array}$ \\
\hline & & CDC $1771-74$ & $\begin{array}{l}\text { CDC }(\mathrm{R} . \text { Facklam }) \\
\text { wound }\end{array}$ \\
\hline IV & S. faecalis & $\begin{array}{l}\text { ATCC } 19433^{\mathrm{T}} \\
\text { F-250 (wild) }\end{array}$ & $\begin{array}{l}\text { ATCC; type strain } \\
\text { Veterans Administration } \\
\text { Medical Center, Cleve- } \\
\text { land, Ohio; blood }\end{array}$ \\
\hline
\end{tabular}

a ATCC, American Type Culture Collection; CDC, Communicable Disease Center.

${ }_{b} \mathrm{~T}=$ type strain.

mixture was incubated at $37^{\circ} \mathrm{C}$ for 1 to $2 \mathrm{~h}$. "Lyseability" was assayed by removing a small sample, bringing the buffer to full-strength saline-ethylenediaminetetraacetate, and then adding $20 \%$ sodium dodecyl sulfate to a final concentration of $1 \%$. Lysis was indicated by a rapid increase in viscosity and a change in the suspension from turbid to opalescent. This method is essentially the method described by Johnson (7).

Extraction of DNA. DNA was extracted by the Marmur method (10), as described by Johnson (7).

DNA base composition. DNA thermal melting curves obtained were in the laboratory of J. Johnson (Virginia Polytechnic Institute and State University, Blacksburg), using Escherichia coli $\mathrm{B}$ as a comparative standard. The guanineplus-cytosine $(\mathrm{G}+\mathrm{C})$ content was calculated by using the following formula: $\mathrm{G}+\mathrm{C}$ content $=2.44 T_{m}-169.25(7,10)$, where $T_{m}$ is the melting temperature.

Preparation of labeled DNA. DNA was labeled in vitro by using $\left[{ }^{3} \mathrm{H}\right]$ thymidine 5 '-triphosphate (New England Nuclear Corp., Boston, Mass.) and a commercially available nick translation kit (Bethesda Research Laboratories, Inc., Gaithersburg, Md.). The radiolabeled DNA was precipitated with ice-cold ethanol and centrifuged in a 1.5-ml Eppendorf reaction tube. The supernatant was removed, and the precipitate was dried for $30 \mathrm{~min}$ in a vacuum desiccator. The DNA was then suspended in $0.1 \times$ standard saline citrate (SSC; $1 \times$ $\mathrm{SSC}$ is $0.15 \mathrm{M} \mathrm{NaCl}$ plus $0.015 \mathrm{M}$ sodium citrate, $\mathrm{pH} 7.0$ ) and stored at $-20^{\circ} \mathrm{C}$.

DNA homology assays. Both labeled and unlabeled DNAs were sheared by sonication, using two 15 -s bursts with a sonicator (Heat Systems-Ultrasonics, Inc.) and a microtip probe at an energy setting of 22 . The DNA was then denatured by heating in a boiling water bath for 5 to $10 \mathrm{~min}$ and quick cooling in an ice bath. The assay was performed by mixing $10 \mu \mathrm{g}$ of sheared denatured labeled DNA and 50 $\mu \mathrm{g}$ of sheared denatured heterologous DNA $(0.5 \mathrm{mg} / \mathrm{ml})$ in 50 $\mu l$ of $0.88 \mathrm{M} \mathrm{NaCl}-10^{-3} \mathrm{M}$ HEPES ( $N$-2-hydroxyethylpiperazine- $N^{\prime}$-2-ethanesulfonic acid) buffer $(\mathrm{pH} 7)$. All reassociation mixtures were incubated for 20 to $24 \mathrm{~h}$ in $1.0-\mathrm{ml}$ Eppendorf vials submerged in a $60^{\circ} \mathrm{C}$ water bath. After incubation $100 \mu \mathrm{l}$ was removed from each tube and placed in a test tube $(12$ by $75 \mathrm{~mm})$ containing $1 \mathrm{ml}$ of assay buffer ( $0.05 \mathrm{M}$ sodium acetate, $0.03 \mathrm{M} \mathrm{NaCl}, 0.5 \mathrm{mM} \mathrm{ZnCl}_{2}, \mathrm{pH}$ 4.6) and $50 \mu$ l of sheared denatured salmon sperm DNA $(0.4$ $\mathrm{mg} / \mathrm{ml}$ ). The contents were mixed with a Vortex mixer, and $50 \mu \mathrm{l}$ of $\mathrm{S} 1$ nuclease (Calbiochem-Behring, La Jolla, Calif.) was added immediately before incubation in a $50^{\circ} \mathrm{C}$ water bath for $1 \mathrm{~h}$. An equal volume of cold $10 \%$ trichloroacetic acid was added to each tube after incubation, and the mixture was placed into a refrigerator $\left(2\right.$ to $\left.6^{\circ} \mathrm{C}\right)$ for $1 \mathrm{~h}$. The precipitates were collected on nitrocellulose filters, dried, placed into scintillation vials, and counted. Each experiment was performed in duplicate with a control containing unlabeled homologous DNA and a control with unlabeled heterologous (salmon sperm) DNA. Homology was calculated by using the number of $\mathrm{S} 1$ nuclease-resistant counts per minute in the homologous reaction as the $100 \%$ value. The value for a background filter (placed in a scintillation vial) and the number of S1-resistant counts per minute in the heterologous reaction was subtracted from all counts before homologies were calculated.

Homologous binding percentage was calculated by dividing the number of counts per minute from a homologous reaction mixture treated with $S 1$ nuclease by the value for a homologous reaction mixture which was not treated with S1 nuclease (J. Johnson, personal communication).

\section{RESULTS}

The $\mathbf{G}+\mathbf{C}$ content and DNA homology. The $\mathrm{G}+\mathrm{C}$ contents of one strain of " $S$. durans," one strain of $S$. faecium, and one strain of $S$. faecalis were $36.2,36.7$, and $35.3 \mathrm{~mol} \%$, respectively. These values were calculated from melting temperatures of $84.2,84.4$, and $84.1^{\circ} \mathrm{C}$, respectively. Other workers have reported similar values $(12,16)$. The DNAs of all strains of enterococci were tested against the DNAs of the labeled American Type Culture Collection type strains of $S$. faecalis and $S$. faecium and one labeled "S. durans" strain (strain CDC 976-79) obtained from the Centers for Disease Control (Table 1). The homologous binding percentages were $100,81.1,75.6$, and $58.2 \%$ for homology groups $I$, II, III, and IV, respectively. Table 3 shows that " $S$. durans," S. faecium, and S. faecalis form four distinct homology groups.

Phenotypic tests. The following results were common to all enterococcal strains: growth in $40 \%$ bile and esculin hydrolysis; growth in $6.5 \% \mathrm{NaCl}$ broth; no acid production in inulin and raffinose; acid production in lactose; and production of group D antigen detectable by co-agglutination (Table 2 ).

Both $S$. faecalis strains and four of five $S$. faecium strains gave results typical of those expected based on the criteria of Facklam $(3,4)$. All eight " $S$. durans" strains tested were typical of the strains described by Facklam $(3,4)$. The " $S$. durans" strains could be further divided into two groups comparable to homology groups I and II (Table 3). Five betahemolytic strains and one alpha-hemolytic strain clotted litmus milk and failed to produce acid from sucrose (homolo- 
gy group I), whereas the remaining two strains were alphahemolytic, did not clot litmus milk, and produced acid from sucrose (homology group II) (Table 2). All four homology group I strains were susceptible to tobramycin and clindamycin, whereas both homology group II strains were resistant to these antimicrobial agents, as determined by the disk diffusion method. Group D antigen was not detectable by latex agglutination in the five beta-hemolytic (homology group I) strains, whereas detectable levels were found by this method in all alpha-hemolytic strains (homology group II strains and the one alpha-hemolytic strain in homology group I).

\section{DISCUSSION}

The primary purpose of this study was to examine the taxonomic relationship between " $S$. durans' and $S$. faecium by using DNA-DNA hybridization and well-characterized strains. Since the first descriptions of these strains, there has been considerable controversy surrounding their classification $(2-6,8,9,12,14-16)$. A recent study dealing with the numeric taxonomy of streptococci provided conflicting data on $S$. faecium, with seven strains divided among four phena. Only two strains of " $S$. durans" were examined, and they both fell into a single phenon along with three strains of $S$. faecium (1). The type strain of $S$. faecium was not used. There is some reason to question the original identification of these " $S$. durans" strains because the biochemical reactions given for this phenon are not typical of " $S$. durans" as described by Facklam $(3,4)$, although one of the strains was the former "type" of " $S$. durans."

Previous studies of DNA homologies of enterococci have yielded conflicting results. This may have been due in part to the failure of some authors to include type strains. For example, in two studies in which type strains were not utilized, $S$. faecium and $S$. faecalis were shown to be homologous by spectrophotometric methods and the hydroxyapatite procedure $(12,16)$. This is in clear conflict with our data and the data of other workers (5). In another study, in which type strains were also not used, only one strain of " $S$. durans" and two strains of $S$. faecium were examined (9). One of the latter strains was homologous with the reference strain of $S$. faecalis, but one was not. The single strain of " $S$. durans" tested was not homologous with the reference strains of $S$. faecalis and $S$. faecium. This study was marred by questions regarding the identification of some organisms since one of the Streptococcus uberis strains included was said to carry the Lancefield group D antigen (9).

A more recent study that examined the DNA relatedness among enterococci used type strains. Of seven " $S$. durans" strains examined, four were homologous with the type strain of $S$. faecium but not with the former " $S$. durans." The other " $S$. durans" strains were homologous with the former "S. durans" but not with the $S$. faecium (5). The fact that some strains were homologous with the former " $S$. durans" but not with the type strain of $S$. faecium is consistent with our data for the same strains. We suspect that the strains identified as " $S$. durans" that were homologous with the type strain of $S$. faecium may have been misclassified phenotypically.

$S$. faecium differs from " $S$. durans" only in that the former consistently produces acid in mannitol- and arabinose-containing media, whereas the latter does not $(3,4)$. These minor differences led to the official reclassification of " $S$. durans" as S. faecium (15) without definitive DNA relatedness studies. Since Facklam (3) and other workers

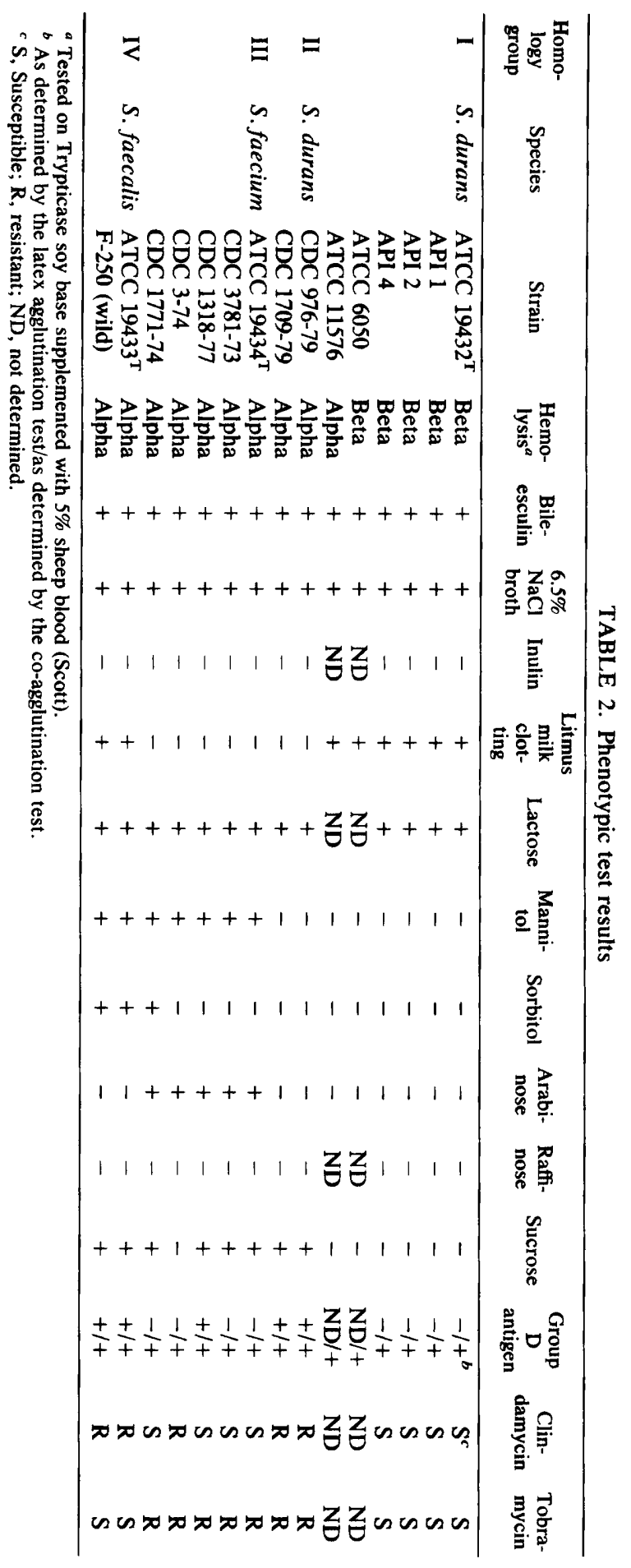


TABLE 3. DNA relatedness among enterococci

\begin{tabular}{|c|c|c|c|c|}
\hline \multirow[b]{2}{*}{ Unlabeled DNA from: } & \multicolumn{4}{|c|}{$\%$ Homology with ${ }^{3} \mathrm{H}$-labeled DNA from: ${ }^{a}$} \\
\hline & $\begin{array}{c}\text { S. durans } \\
\text { ATCC } 19432^{\mathrm{T}}\end{array}$ & $\begin{array}{l}\text { S. durans } \\
\text { CDC } 976-79\end{array}$ & $\begin{array}{l}\text { S. faecium } \\
\text { ATCC } 19434^{\mathrm{T}}\end{array}$ & $\begin{array}{l}\text { S. faecalis } \\
\text { ATCC } 19433^{\mathrm{T}}\end{array}$ \\
\hline \multicolumn{5}{|c|}{ S. durans (homology group I) } \\
\hline ATCC $19432^{\mathrm{T}}$ & 100 & 15 & 22 & 17 \\
\hline API 1 (= CDC SS497) & 89 & 13 & 23 & 13 \\
\hline API $2(=$ CDC SS661) & 100 & 16 & 19 & 7 \\
\hline API 4 (= CDC SS8) & 100 & 15 & 19 & 10 \\
\hline ATCC 6056 & 91 & 16 & 15 & 7 \\
\hline ATCC 11576 & 75 & 12 & 18 & 0 \\
\hline \multicolumn{5}{|c|}{ S. durans (homology group II) } \\
\hline CDC 976-79 & 21 & 100 & 21 & 7 \\
\hline CDC 1709-79 & 23 & 81 & 28 & 1 \\
\hline \multicolumn{5}{|c|}{ S. faecium (homology group III) } \\
\hline ATCC $19434^{\mathrm{T}}$ & 11 & 14 & 100 & 0 \\
\hline CDC 3781-73 & 16 & 11 & 86 & 0 \\
\hline CDC 1318-77 & 33 & 11 & 91 & 8 \\
\hline CDC 3-74 & 26 & 11 & 72 & 9 \\
\hline CDC 1771-74 & 28 & 10 & 80 & 1 \\
\hline \multicolumn{5}{|c|}{ S. faecalis (homology group IV) } \\
\hline ATCC $19433^{\mathrm{T}}$ & 8 & 4 & 8 & 100 \\
\hline F-250 (wild) & 8 & 4 & 5 & 100 \\
\hline
\end{tabular}

${ }^{a}$ Data are expressed as averages from at least two experiments.

continue to use " $S$. durans," there has been continuing confusion over the taxonomy of these enterococci.

The strains used in the present work were obtained from reference laboratories and were confirmed by using a battery of biochemical and physiological tests. We also used type and former type strains of the three species studied, including the same three type strains used by Farrow et al. (5). Our results, like those of Farrow and his co-workers, suggest that " $S$. durans" is a species separate from $S$. faecium and $S$. faecalis. We have also described a second homology group, group II, similar to " $S$. durans," which apparently can be separated phenotypically from typical " $S$. durans" strains on the basis of clot formation in litmus milk, production of acid from sucrose, and response to clindamycin and tobramycin. The two strains in homology group II may represent a new species, but at present the data supporting such a proposal are insufficient.

We propose that " $S$. durans" of our homology group I be reclassified as Streptococcus durans sp. nov.

Streptococcus durans sp. nov. Was originally named by Sherman and Wing in 1934 for its tolerance to heat and desiccation. The organisms are gram-positive cocci that occur in pairs or chains of varying length (usually less than six cells). After $24 \mathrm{~h}$ of growth in 5 to $10 \% \mathrm{CO}_{2}$ on Trypticase soy agar supplemented with $5 \%$ sheep blood, colonies are 1 to $2 \mathrm{~mm}$ in diameter with a small zone of beta- or alphahemolysis. The bacteria are facultatively anaerobic. Growth occurs in the presence of $6.5 \% \mathrm{NaCl}$ and in the presence of $40 \%$ bile. Esculin is hydrolyzed. Mannitol, sorbitol, sucrose, and arabinose are not fermented, but lactose is fermented. Clot formation occurs in litmus milk. Lancefield Group D antigen is expressed. The DNA base composition is $36 \mathrm{~mol} \%$ $\mathrm{G}+\mathrm{C}$. DNA relatedness show that this taxon is separate from $S$. faecium and $S$. faecalis. The proposed type strain is strain ATCC 19432.

\section{ACKNOWLEDGMENTS}

We are grateful to J. L. Johnson (Virginia Polytechnic Institute and State University) for showing us the $\mathrm{S} 1$ nuclease procedure and allowing one of us (R.G.K.) to work in his laboratory. We also thank R. Facklam and J. Goldstein for the strains of enterococci used and Elizabeth Williams for excellent secretarial assistance.

This work was supported by the Veterans Administration.

\section{LITERATURE CITED}

1. Bridge, P. D., and P. H. A. Sneath. 1983. Numerical taxonomy of Streptococcus. J. Gen. Microbiol. 129:565-597.

2. Deibel, R. H., D. E. Lake, and C. F. Niven, Jr. 1963. Physiology of the enterococci as related to their taxonomy. J. Bacteriol. 86:1275-1282.

3. Facklam, R. R. 1972. Recognition of group D streptococcal species of human origin by biochemical and physiological tests. Appl. Microbiol. 23:1131-1139.

4. Facklam, R. R. 1980. Streptococci and aerococci, p. 88-110. In E. H. Lennette, A. Balow, W. J. Hausler, Jr., and J. P. Truant (ed.), Manual of clinical microbiology, 3rd ed. American Society for Microbiology, Washington, D.C.

5. Farrow, J. A. E., D. Jones, B. A. Phillips, and M. D. Collins. 1983. Taxonomic studies on some group D streptococci. J. Gen. Microbiol. 129:1423-1432.

6. Hartman, P. A., G. W. Reinhold, and D. S. Saraswat. 1966. Indicator organisms-a review. I. Taxonomy of the fecal streptococci. Int. J. Syst. Bacteriol. 16:197-221.

7. Johnson, J. L. 1981. Genetic characterization, p. 450-475. In P. Gerhart (ed.), Manual of methods for general bacteriology. American Society for Microbiology, Washington, D.C.

8. Kalina, A. P. 1970. The taxonomy and nomenclature of enterococci. Int. J. Syst. Bacteriol. 20:185-189.

9. Klipper-Balz, R., G. Fisher, and K. H. Schleifer. 1982. Nucleic acid hybridization of group D streptococci. Curr. Microbiol. 7:245-250.

10. Marmur, J., and P. Doty. 1961. A procedure for the isolation of deoxyribonucleic acid from microorganisms. J. Mol. Biol. 3:209-218.

11. Marmur, J., and P. Doty. 1961. Thermal renaturation of DNA. J. Mol. Biol. 3:585-594.

12. Roop, D. R., J. O. Mundt, and W. S. Riggsby. 1974. Deoxyribonucleic acid hybridization studies among some strains of group D and group N streptococci. Int. J. Syst. Bacteriol. 24:330-337. 
13. Setterstrom, J. A., A. Gross, and R. S. Stanko. 1979. Comparison of Minitek and conventional methods for the biochemical characterization of oral streptococci. J. Clin. Microbiol. 10:409414.

14. Sherman, J. M., and H. V. Wing. 1937. Streptococcus durans. J. Dairy Sci. 20:165-167.
15. Skerman, V. B. D., V. McGowan, and P. H. A. Sneath (ed.). 1980. Approved lists of bacterial names. Int. J. Syst. Bacteriol. 30:225-420.

16. Vaughan, D. H., W. S. Riggsby, and J. O. Mundt. 1977. Deoxyribonucleic acid relatedness of strains of yellow-pigmented, group D streptococci. Int. J. Syst. Bacteriol. 29:204-212. 